\title{
Joaquim Nabuco, artista ${ }^{1}$
}

José Américo Miranda Universidade Federal de Minas Gerais

Resumo: Este artigo analisa a obra de Joaquim Nabuco, Pensées détachées et souvenirs, escrita e publicada em francês, como uma obra de arte. Joaquim Nabuco não se considerava um artista, mas Machado de Assis, grande escritor e grande critico de seu tempo, o chamou de "artista", numa carta que lhe dirigiu - carta que é, ela própria, uma excelente peça de crítica literária. Palavras-chave: Literatura brasileira, Joaquim Nabuco, Machado de Assis

\section{I}

Joaquim Nabuco nasceu em 1849 e, na década de 1860, foi aluno do Colégio Pedro II, onde escrevia poesias de circunstância, que recitava em saraus literários. Por essa época, eram relativamente intensas as atividades de associações literárias e musicais no Rio de Janeiro. Ensaiava-se o espírito associativo, que resultaria na fundação, em 1897, da Academia Brasileira de Letras.

Havia, ao final da década de 1850 e início da de 1860, o Grêmio Literário Português, o Retiro Literário Português, o Ginásio Científico-Literário

1. Este artigo é resultado parcial da pesquisa de Pós-Doutorado realizada, durante o ano de 2010, junto ao Programa de Pós-Graduação em Literatura Brasileira do Departamento de Letras Clássicas e Vernáculas da Universidade de São Paulo (USP). 
Brasileiro, a Academia Filosófica, a Sociedade Arcádia Brasileira e a Sociedade Ensaios Literários, e, também, a Sociedade Petalógica. O feitio dessas associações era bem visto pelos intelectuais, como estímulo à vida cultural e literária. O momento era particularmente propício a elas, pois, em 9 de janeiro de 1866, Machado de Assis, na "Semana Literária", do Diário do Rio de Janeiro, assim se expressava acerca do nível dos livros publicados no país: "A temperatura literária está abaixo de zero."

Machado de Assis foi um incentivador dessas instituições e foi por elas incentivado. Era bibliotecário da Arcádia Brasileira e frequentava as reuniões do Retiro Literário Português, onde, em 1862, numa reunião, recitou a poesia "A uma criança", e em outra, "A caridade" - ambas publicadas em Crisálidas (1864), seu primeiro livro de poesia, a primeira com o título trocado para "Quinze anos".

Machado ligou-se, também, a um grupo de intelectuais e artistas que se reunia na Rua da Quitanda, n. 6, onde lhe representaram, a 22 de novembro de 1864, a comédia Quase ministro. Nessa mesma reunião, recitou Machado de Assis "O epitáfio do México", outra das poesias de Crisálidas. A ser verdadeira a data da reunião, a leitura da poesia de Machado não seria, como afirma Raimundo Magalhães Júnior, uma divulgação em primeira mão, pois o livro saíra do prelo em setembro de 1864, como informa o mesmo autor. ${ }^{4}$

Uma outra associação literária - que aqui nos interessa diretamente, por haver reunido, pela primeira vez, os dois personagens deste artigo, Joaquim Nabuco e Machado de Assis - foi fundada em 15 de setembro de 1865, quando se comemorava o centenário do nascimento de Bocage. Era a Arcádia Fluminense. José Feliciano de Castilho foi aclamado seu primeiro presidente. Em suas reuniões, Machado de Assis leu algumas poesias; e num de seus saraus, o de 28 de dezembro de 1865, foi representada a comédia Os deuses de casaca, obra a que nada falta para que se a considere genial.

Um dos saraus da Arcádia Fluminense, realizado entre os dias 15 de setembro e 25 de novembro de 1865, no dia 14 de outubro, conforme noticiou o Diário do Rio de Janeiro em 17 do mesmo mês, teve a excepcional duração de

2. ASSIS. Obra completa, v. III, p. 841.

3. Cf. MAGAlHÃeS JÚNIOR. À sombra das Arcádias. In: Vida e obra de Machado de Assis, v. 1, p. 152-165.

4. Cf. MAgalhães JúNIOR. À sombra das Arcádias e O adeus a Corina. In: Vida e obra de Machado de Assis, v. 1, p. 152-165 e p. 213-227.

5. Cf. HOUAISS, Antônio et al. Introdução crítico-filológica, p. 41. 
cinco horas, tendo começado antes das 9 horas da noite e terminado por volta das 2 horas da madrugada. De seu extenso programa lítero-musical, consta o poema "A tomada de Uruguaiana", de Joaquim José Teixeira, "No espaço", de Machado de Assis, que a incluiu, depois, no livro Falenas (1870), "Arcanos e futuro", de Joaquim Nabuco, e "Uruguaiana", de Augusto Emílio Zaluar.

Em 25 de novembro de 1865, fez-se outra sessão da Arcádia Fluminense, com a presença do Imperador, da Imperatriz e de outros membros da família imperial. D. Pedro II acabava de regressar de Uruguaiana, onde fora assistir à rendição das forças paraguaias sitiadas naquela localidade. Nessa reunião, foi tocada e cantada a "Cantata da Arcádia Fluminense", alusiva ao sucesso de Uruguaiana, com letra de Machado de Assis e música de José Amat.

Não fora necessária essa tentativa de ordenação cronológica e essa minúcia no exame da programação das sessões da Arcádia Fluminense, não nos víssemos num emaranhado cipoal de informações contraditórias em seus detalhes. São fatos: Machado de Assis e Joaquim Nabuco, na época adolescente, participaram, ambos, dos saraus da Arcádia Fluminense; as hostilidades entre Brasil e Paraguai começaram em dezembro de 1864; as forças paraguaias chegaram a Uruguaiana em agosto de 1865, onde ficaram sitiadas e acabaram por se render em outubro do mesmo ano. Portanto, justifica-se a presença de Uruguaiana já nas poesias da sessão da Arcádia Fluminense realizada em outubro.

Meses antes disso tudo, em 31 de janeiro de 1865, no folhetim "Ao acaso", do Diário do Rio de Janeiro, Machado de Assis havia-se referido elogiosamente ao "jovem estreante da poesia" Joaquim Nabuco. Já no dia seguinte, $1^{\circ}$. de fevereiro, o "jovem estreante" escreveu sua primeira carta a Machado de Assis. Foi o início de uma correspondência que se prolongou por aproximadamente 43 anos. A última carta veio dos Estados Unidos, onde Nabuco era embaixador, datada de 3 de setembro de 1908 - 26 dias antes da morte do grande escritor, autor de Dom Casmurro.

No folhetim do Diário do Rio de Janeiro, "Ao Acaso", de 31 de janeiro de 1865, depois de atribuir o início do "reinado da virtude" - com a paz universal dando "um repouso definitivo aos espíritos" - a um cometa que passava pelo céu, e do qual se havia previsto que destruiria o planeta e a humanidade, pôs-se a falar de guerra e poesia:

6. Cf. MAGAlHÃes JúNIOR. À sombra das Arcádias e O adeus a Corina. In: Vida e obra de Machado de Assis, v. 1, p. 152-165 e p. 213-227. 
Nada sei de Marte e de Apolo, mas sei que os dois filhos de Saturno se desavieram por coisas sérias; estando a razão do lado do pai da poesia.

Que o deus Marte acenda a guerra entre os estados, vá. É esse o seu ofício único. Mas que, ao som da metralha favoreça aos vândalos a subida à montanha sagrada, isso não. Pois não foi outra coisa. Mal soaram os primeiros tiros em Paissandu, os poetastros, vendo que os poetas afinavam a lira, não se deixaram ficar em casa. Travaram da guitarra e lá se foram atrás dos poetas, cobertos e disfarçados, para melhor iludir o pai da poesia. Foi uma verdadeira confusão.

Ou eu me engano, ou o único perigo da guerra atual é este.

A Guerra do Paraguai tinha começado: o episódio de Paissandu terminara, com a tomada da cidade pelas tropas brasileiras associadas ao uruguaio Venâncio Flores, em 2 de janeiro daquele ano. A julgar pela crônica de Machado de Assis, os jornais do Rio de Janeiro se encheram de versos (ruins) alusivos ao acontecimento.

Na sequência do folhetim, referiu-se ele ao jovem Joaquim Nabuco com as seguintes palavras:

Já que falo em poetas, escreverei aqui o nome de um jovem estreante da poesia, a quem não falta vocação, nem espontaneidade, mas que deve curar de aperfeiçoar-se pelo estudo. É o sr. Joaquim Nabuco. Tem 15 anos apenas. Os seus versos não são decerto perfeitos: o jovem poeta balbucia apenas; falta-lhe compulsar modelos, estudar a língua, ultimar a arte; mas se lhe faltam os requisitos que só o estudo pode dar, nem por isso se lhe desconhece desde já uma tendência pronunciada e uma imaginação viçosa. Tem o direito de contar com o futuro. ${ }^{8}$

Se há uma ponta de elogio no texto, há também reprimenda, como era de costume no exigente crítico. Na verdade, Machado de Assis tentava salvar esse nome de entre os "vândalos" e "poetastros'. O jovem poeta era filho do senador de mesmo nome, que o cronista vira atuar no senado do Império, quando foi cronista parlamentar, no início da década de 1860 . $^{9}$

7. ASSIS. Crônicas (1864-1867), p. 288-289.

8. ASSIS. Crônicas (1864-1867), p. 289.

9. Cf. ASSIS. A semana (1894-1895), v. 2, p. 414-419; ASSIS. O velho senado. In: Páginas recolhidas, p. 147-169. 
Diante dessas palavras, estampadas em jornal de ampla circulação, apressou-se o jovem "poeta" a dar explicações ao folhetinista, para pôr os pingos nos is e não deixá-lo iludido de si.

Na edição da correspondência trocada entre Joaquim Nabuco e Machao de Assis, Graça Aranha introduziu uma única nota a esta carta, logo após o protocolar "Meu caro Senhor". Diz a nota:

Joaquim Nabuco tinha 15 anos; era aluno do Colégio Pedro II e escrevia por essa época poesias de circunstância que recitava nos saraus literários. Na sessão da Arcádia Fluminense, em 25 de novembro de 1865, leu em presença do imperador e da imperatriz e das altezas imperiais a poesia "Uruguaiana".

Esta primeira carta de Nabuco responde à saudação que Machado de Assis lhe fizera na sua revista da semana "Ao Acaso" (folhetim do Diário do Rio de Janeiro, de 31 de janeiro de 1865) nas seguintes palavras:

“...Já que falo em poetas etc." [segue o trecho citado acima, neste artigo]. ${ }^{10}$

O modo pelo qual Graça Aranha dispõe as informações, numa única nota - em que pese a clareza com que declara as datas dos acontecimentos -, associado às informações fragmentárias de que dispomos, faz crer que o elogio de Machado de Assis derivasse da poesia "Uruguaiana". Pelo menos, foi o que entendeu José Murilo de Carvalho, no prefácio à terceira edição da correspondência, onde diz: "A primeira carta é de Nabuco, um rapazola de 15 anos, aluno do Colégio Pedro II, que escreveu em 1865 agradecendo comentários elogiosos feitos por Machado, então com 25 anos, a poema patriótico sobre a rendição de Uruguaiana que recitara em presença do imperador."

Das informações disponíveis, que demonstram o conhecimento que tinha Machado de Assis das atividades poéticas de Joaquim Nabuco, principalmente das datas da carta e da sessão em que ocorreu a leitura do poema "Uruguaiana", não é possível atribuir a esse poema a motivação da carta nem a do elogio no folhetim. A carta é de 1ํ. de fevereiro, o poema foi lido em 25 de novembro ambos os meses de 1865; e o folhetim de Machado de Assis havia sido publicado em 31 de janeiro do mesmo ano. Portanto, Machado de Assis conhecia as tentativas

10. ARANHA. In: Machado de Assis e Joaquim Nabuco: correspondência, p. 89. (Nota 1)

11. CARValho. As duas repúblicas, p. 9. 
poéticas do aluno do Colégio Pedro II desde pelo menos cerca de um ano antes da sessão da Arcádia Fluminense em que foi recebido o Imperador, que acabava de chegar de Uruguaiana. As forças paraguaias chegaram a Uruguaiana em agosto, foram cercadas e renderam-se em outubro de 1865, na presença de D. Pedro II e da família imperial. Em 25 de novembro, estava o Imperador no Rio de Janeiro, onde marcou presença na já mencionada sessão da Arcádia Fluminense.

Mas retrocedamos aos meses de janeiro e fevereiro. Na carta que dirigiu a Machado de Assis, Joaquim Nabuco foi direto ao assunto e muito claro quanto a suas pretensões:

Tenho em vista o Diário de ontem, na crônica - "Ao acaso" deparo com algumas linhas ao meu respeito, caídas de sua pena; li e reli o que sobre mim escreveu, e depois de meditar sobre estas linhas decidi-me a aventar sobre elas as duas considerações que se seguem:

Não sou poeta; as minhas toscas composições, escritas nas minhas horas vagas, ainda não pretendem a tanto; o título pomposo - poeta - que, por extrema bondade, e complacência, dignou-se-me aplicar, poderia, esmagando a minha nula valia, encher-me de um orgulho sem fundamento, que me elevasse acima do que eu realmente sou [...].

Escrevo versos, é certo; porém estes versos, sem cadência e sem harmonia, não podem elevar o seu autor à altura de poeta [...].

Esta é a primeira consideração que a leitura de suas linhas sugeriu em minha mente; de mais, cabe-me dizer-lho: de uma certa idade em diante, pretendo me não mais aplicar à poesia [...].

...um dia virá, e este dia talvez esteja perto, no qual me desligue completamente desse mundo de visionários [o dos poetas], para ir tomar parte no grêmio daqueles que, mais chegados às realidades da vida, consideram este mundo como ele realmente é. ${ }^{13}$

Graça Aranha, na "Introdução" à correspondência de Joaquim Nabuco com Machado de Assis, refere-se ao iniciante nas letras, logo no início de seu texto,

12. As informações sobre a Guerra do Paraguai utilizadas neste artigo foram colhidas em HOLANDA. Dir. História geral da civilização brasileira: II - O Brasil monárquico - do império à república; SKIDMORE. Uma história do Brasil; e no Novo dicionário de História do Brasil.

13. NABUCO. In: ARANHA. Org. Machado de Assis e Joaquim Nabuco: correspondência, p. 89-90. 
como jovem "que publica versos assinalados pelos críticos", dando a entender que Machado lhe conheceu a poesia primeiro pela imprensa.

Tudo isso pode parecer de pouca importância: "São migalhas da história, mas as migalhas devem ser recolhidas." ${ }^{14}$

\section{II}

Machado de Assis, que elaborou "um pequeno código de crítica", que pôs em prática ao longo de sua carreira, quando analisava textos literários, especialmente quando se tratava de poesia, fez crítica sob o nome próprio de crítica, fez crítica em prefácios ou apresentações a livros de poetas (muitos deles estreantes), fez crítica em crônicas e em artigos longos (especialmente dedicados à literatura, como em "Notícia da atual literatura brasileira - Instinto de nacionalidade" e em "A nova geração"), emitiu juízos críticos em cartas a autores que lhe enviavam livros e a terceiros (geralmente seus amigos). Sob a rubrica de crítica literária, o escritor estava em seu elemento próprio, como nos "Comentários da Semana", que manteve, a partir do início de 1862, no Diário do Rio de Janeiro, em que dedicou alguns de seus folhetins exclusivamente à avaliação de obras recentemente publicadas; nos prefácios e apresentações a livros de autores estreantes ou não, como nos prefácios a Névoas matutinas, de Lúcio de Mendonça, a Harmonias errantes, de Francisco de Castro, às Meridionais, de Alberto de Oliveira, às Miragens, de Enéas Galvão, a O Guarani, de José de Alencar, às Sinfonias, de Raimundo Correia, embora a situação do texto na própria obra apresentada pudesse limitar o alcance da crítica, ele a praticou do mesmo modo e com o mesmo método; nas crônicas que manteve em diversas séries de diversos jornais, a apreciação de obras literárias vinha em meio a outros assuntos, era registro da vivência cotidiana do escritor e fazia parte de sua obrigação de folhetinista; por fim, na correspondência com amigos, como na carta a Joaquim Nabuco, datada de 19 de agosto de 1906, que Mário de Alencar fez figurar como capítulo no volume Crítica por Machado de Assis, que publicou em 1910, agia com a mesma imparcialidade e falava como se o autor a que se dirigia desconhecesse seu próprio texto. Esta é uma das "duas

14. ASSIS. A semana (1894-1895), v. 2, p. 417.

15. ATAÍDE. Machado de Assis, o crítico. In: ASSIS. Obra completa, v. III, p. 782. 
ou três" cartas a que se poderia aplicar a ideia de que foram "concebidas como artigos", conforme observou Antonio Candido a propósito da raridade desse tipo de carta na correspondência de Machado de Assis com seus amigos.

Na "Carta-prefácio" a Miragens, de Eneias Galvão, obra publicada em 1885, Machado de Assis assumiu a atitude didática, que atribuía à crítica literária desde 1865, quando, em "O ideal do crítico", dizia ver nessa atividade do espírito a função de "influir e dirigir", "o meio de reerguer os ânimos, promover os estímulos, guiar os estreantes, corrigir os talentos feitos". ${ }^{17}$ Partilhava dessa mesma visão o autor que ele analisa, Joaquim Nabuco, que anotou, no livro analisado, este "pensamento": "É grande e útil a função da crítica. Ela é quem forma o gosto do público. São beneméritos aqueles que, sobre ter bom gosto, emprestam esse gosto a toda a gente." (III: 197)

Machado de Assis, depois de apontar as lacunas do livro de Eneias Galvão, tanto no plano da matéria tratada e como no plano formal, deu ao poeta o seguinte alerta: “...no esmero do verso, não vá ao ponto de cercear a inspiração. Esta é a alma da poesia, e como toda a alma precisa de um corpo, força é dar-lho, e quanto mais belo melhor; mas nem tudo deve ser corpo. A perfeição, neste caso, é a harmonia das partes." ${ }^{19}$

Temos aí, em fórmula concisa, os itens do programa analítico empregado pelo crítico, que afirmara, vinte anos antes, que "crítica é análise". ${ }^{20}$ De fato, em toda a crítica machadiana podem ser encontradas certas constantes: em primeiro lugar, ele exercita as duas faces de sua própria atividade - o elogio vem sempre de par com a ressalva; em segundo, ele examina as duas faces do objeto - a "inspiração", alma da poesia, e a técnica, o "esmero do verso", o corpo. Nesse mesmo trecho tão breve, encontramos, ainda, o terceiro elemento da análise:

16. Cf. CANDIDO. Nota inicial, p. 11.

17. Assis. O ideal do crítico. In: Obra completa em quatro volumes, v. III, p. 1102-1103.

18. NABUCO. Pensamentos soltos, livro III, pensamento 197. Em todas as referências a essa obra, utilizaremos este sistema de indicar o livro em algarismo romano e o fragmento em arábico. A tradução é de Carolina Nabuco.

19. ASSIS. Carta-prefácio (Eneias Galvão: Miragens). In: Obra completa em quatro volumes, v.III, p. 1305.

20. ASsis. O ideal do crítico. In: Obra completa em quatro volumes, v. III, p. 1102. 
"a perfeição", "harmonia das partes", devendo-se entender aí, pela lógica de encadeamento dos períodos, a adequação da forma à matéria da expressão. Diz ele ao poeta iniciante, no começo da mencionada "Carta-prefácio": "Com os anos adquire-se a firmeza, domina-se a arte, multiplicam-se os recursos, busca-se a perfeição que é a ambição e o dever de todos os que tomam da pena para traduzir no papel as suas ideias e sensações."

Falava Machado de Assis do alto dos seus vinte anos de prática de crítica literária, vinte anos em que cumprira à risca o programa exposto em "O ideal do crítico". Eram estes os seus princípios: "meditar profundamente" sobre a obra, "procurar-lhe o sentido íntimo"; "aplicar-lhe as leis poéticas"; por fim, ver "até que ponto a imaginação e a verdade conferenciaram para aquela produção." Já possuía ele, à altura em que redigiu a "Carta-prefácio", a firmeza, o domínio, a riqueza de recursos necessários ao exercício da crítica. Ao longo do tempo, os três aspectos de sua poética da crítica ("seu pequeno código de crítica") receberam, a cada ocasião, denominações diferentes. A "inspiração" é, na proposição do método, "o sentido íntimo" que cabe ao crítico investigar - e ela aparece, a cada crítica, com diversa denominação; o "esmero do verso" consiste na aplicação das "leis poéticas" - os aspectos formais, também, são referidos, a cada crítica, com variado vocabulário; e "a perfeição", a "harmonia das partes", é a conferência, o acordo das partes entre si na obra poética - concordância que lhe confere a sua (dela) "verdade". Essa concordância, nas críticas do autor, fica muitas vezes implícita - quando há restrições, quase sempre as há, a obra não é "perfeita", o que implica desajuste entre as partes, desarmonia.

Muito poucas vezes, em toda a sua carreira no exercício da crítica literária, julgou ele que algum poeta falhava em dois ou três dos aspectos que sistematicamente avaliava - o mais comum era o elogio das faculdades poéticas potenciais do poeta analisado, a revelação e valorização da tendência dominante em determinada obra; as objeções costumavam ser dirigidas aos aspectos técnicos, formais, mais objetivos. Menos frequentemente apontava o crítico a inadequação ou impropriedade de alguns aspectos da matéria de que tratava o poeta - eram restrições à imaginação, à inspiração, à "alma" da poesia. Quando a forma era correta, não deixava ele de assinalá-la. Muito mais raramente deixou de constatar e fazer ver ao poeta e ao leitor algum senão nas obras que julgou.

Um dos casos em que Machado de Assis não fez restrição alguma à obra que examinou é justamente a página dirigida a Joaquim Nabuco, em 1906, sobre seu livro Pensées détachées et souvenirs. 
Não se trata, no caso desse livro, propriamente, de um livro de poesia. Mas Machado de Assis reconheceu no autor, por meio da obra, e as aponta a seu público, "faculdades de artista". Vê-se que não era estreita a noção de poesia do crítico. Lembre-se o que disse de Iracema: "Tal é o livro do sr. José de Alencar, fruto do estudo, e da meditação, escrito com sentimento e consciência. [...] Esperase dele outros poemas em prosa. Poema lhe chamamos a este, sem curar de saber se é antes uma lenda, se um romance: o futuro chamar-lhe-á obra-prima., ${ }^{21}$ Encontrase Machado de Assis do lado dos clássicos da Antiguidade: está distante do preconceito de que a narrativa não deva ou não possa ser matéria de poesia; pelo contrário, nas formas narrativas, a poesia estaria lidando com o objeto que lhe é mais apropriado. A clareza da expressão é um dos pontos-chave do pensamento machadiano; e se é assim, todo signo deve ter uma relação simples e não distorcida com aquilo que significa; então, nada mais certo e justo que aquilo que se passa no tempo, as ações que se articulam numa narrativa, se expressem por meio de signos sucessivos, como são os da linguagem da poesia. ${ }^{22}$

Não foi essa a única ocasião em que o crítico se viu às voltas com poesia sem versos. Apenas passados quatro anos do escrito sobre Iracema, analisou ele o livro Entre o céu e a terra, de Flávio Reimar (nome literário de Gentil Homem de Almeida Braga). E o que diz ele? "Poeta" o chama, e mais de uma vez; mas o livro é em prosa.

Entre o céu e a terra é o título de um livro em prosa que Flávio Reimar me enviou do Maranhão. Ele lá explica no prólogo a razão deste título, que lhe não parece congruente com o livro. Eu creio que o é, se the procurarmos a razão do título, não na letra, mas no espírito da obra. Aqueles escritos diversos, reunidos caprichosamente num volume, não são bem do céu nem bem da terra, posto falem da terra e do céu - de coisas alegres e de coisas tristes, de filosofia e saudade, de lágrimas e sorrisos -, evocações do passado e arroubos de imaginação e devaneios, coisas cá de baixo e coisas lá de cima. O título exprime bem a unidade do livro no meio da diversidade dos assuntos. ${ }^{23}$

21. ASSIS. Obra completa em quatro volumes, v. III, p. 1116.

22. Cf. o ideal clássico da adequação entre o signo e seu objeto em LESSING. Laocoonte, p. 165-175.

23. ASSIS. Obra completa em quatro volumes, v. III, p. 1186. 
O crítico constata, no todo do volume, a "verdade", a "perfeição" da obra - sob a forma da "harmonia" da matéria tratada com a forma. Há no livro "evocações do passado", "arroubos de imaginação e devaneios" - há "inspiração", "alma da poesia"; é a matéria de que trata o poeta. Quanto às peças que compõem o livro, as páginas, em sua diversidade, "não admitem análises nem resumos", em estudo tão breve: "Pelos assunto, pela forma, pelas proporções escapam à análise, o que é uma felicidade para o leitor que entrará assim em terra desconhecida para ele." A variedade dos assuntos era uma de suas obsessões: ele a aconselhava aos poetas ensimesmados - "alargar a vista a outros horizontes", "lance os olhos além de si mesmo" (foi o que aconselhou ao estreante Eneias Galvão).

E não são estas - a variedade dos assuntos e a forma em prosa - as únicas coincidências entre o livro de Flávio Reimar e o de Nabuco: ambos são autores que foram tomados às musas pela vida prática. De Flávio Reimar, disse Machado de Assis que "desceu um dia das regiões da poesia para entrar na vida prática das coisas públicas”, de onde ressurgiu com Entre o céu e a terra; dos Pensées détachées, de Nabuco, disse que apareciam justamente quando o autor deles cuidava de "tarefas práticas de ordem política." Nabuco, por aqueles dias, presidia, no Rio de Janeiro, a Terceira Conferência Pan-Americana, que ele conseguira, por seu desempenho na função de embaixador brasileiro em Washington, fazer que acontecesse no Brasil, reforçando o pan-americanismo como orientação da política externa do país.

Joaquim Nabuco, quando tinha quinze anos de idade, no dia seguinte ao da publicação do folhetim em que Machado de Assis mencionara seu nome, apressou-se, como ficou registrado acima, em responder ao folhetinista. Em sua resposta foi claro e sincero: não se considerava poeta; apenas fazia versos sem harmonia, enquanto aguardava o tempo da maturidade, em que se lançaria às tarefas mais chegadas às realidades da vida.

Para Nabuco, a intervenção nas realidades da vida implicou, sobretudo, o abandono dos princípios e interesses de sua classe social; para Machado de Assis, pelo apego às musas e pela graça delas, o caminho foi percorrido no sentido contrário. Para referir tal cruzamento de trajetórias encontrou Graça Aranha estas palavras:

O heró́smo de Joaquim Nabuco foi o de separar-se da aristocracia e fazer a abolição. O heroísmo de Machado de Assis foi uma marcha inversa, da plebe à aristocracia pela ascensão espiritual. Ambos tiveram 
de romper com as suas classes e heroicamente afirmar as próprias personalidades. ${ }^{24}$

Em seu livro de 1906, Joaquim Nabuco volta, num trecho em que se poderia ler uma afetação de modéstia, a insistir na ideia de que não se aplicou como podia ao ofício da literatura; se foi poeta ou artista, só o pode ter sido por intuição, espontaneamente, sem esforço, sem treinamento, sem aprendizado específico:

Ciência alguma estudei, língua alguma possuo, ignoro os processos de todas as artes; logo não sou escritor. Não me filio em matéria de pensamento, nem aos vertebrados, nem aos articulados, mas aos simples espongiários do grande oceano humano. A exemplo da esponja, não faço senão embeber-me da sua onda, não sentindo o amargor, mas somente a frescura. (III: 52)

Na carta datada de 19 de agosto de 1906, em que avalia o livro recém-publicado por Joaquim Nabuco, Pensées détachées et souvenirs, Machado de Assis, menciona, logo de início, a circunstância de o livro haver aparecido justamente quando Nabuco cuidava de "tarefas práticas de ordem política." Em diversas outras ocasiões, o crítico se deparara com o problema do conflito entre a dedicação às musas e as atividades práticas a que eram chamados os poetas e escritores. Essa foi uma questão para ele logo no início de sua carreira de cronista parlamentar, no Diário do Rio de Janeiro, jornal a que fora convocado por Quintino Bocaiúva, por ocasião de sua reabertura, após a suspensão de sua publicação, que ocorrera pouco depois de José de Alencar deixar sua direção. ${ }^{26}$ Nas páginas desse jornal, numa das crônicas que publicou sob o título de "Ao acaso", em 5 de junho de 1864, esteve presente essa questão: o barão de São Lourenço discursara no senado naquela semana, e, no discurso, disse mal dos poetas como homens públicos. Foi o motivo para que o cronista enumerasse "meia dúzia entre mil" exemplos de poetas que serviram a suas pátrias, exercendo funções públicas: Dante fora por 14

24. ARANHA. Introdução. In: Machado de Assis e Joaquim Nabuco: correspondência, p. 25.

25. ASSIS. Obra completa em quatro volumes, v. III, p. 1342.

26. Cf. MAGAlHÃes JÚNIOR. Vida e obra de Machado de Assis, v. I, p. 133. 
vezes embaixador da República de Florença; Chateaubriand havia sido embaixador de França; Gladstone, chanceler do tesouro britânico, comentara Homero e ilustrara as letras inglesas; Lamartine servira a sua pátria como diplomata e como presidente da República; Garrett acomodara as musas no gabinete de ministro; Martinez de La Roza fora muitas vezes ministro da coroa espanhola. E entre os nossos, ele mencionou Alexandre de Gusmão, o visconde da Pedra Branca, José Bonifácio, o marquês de Paranaguá, que "souberam aliar os dons das musas com os encargos da coisa pública."

Alguns anos mais tarde, a 2 de julho de 1872, avaliando, a pedido do conselheiro Lopes Neto, obras do poeta chileno Guilherme Malta, que exercia funções públicas em seu país, reconheceu que "a causa pública tem roubado muito talento às tarefas literárias". Falava ele, nesse caso, em "nações recémnascidas e mal assentes em suas bases políticas", de modo que foi levado a dizer também:

A mesma coisa se dá na nossa pátria; mas já os enfeitiçados da política vão compreendendo que não há incompatibilidade entre ela e as musas, e, sem de todo lançarem o hábito às ervas, o que não é fácil, é certo que voltam de quando em quando a retemperar-se na imortal juvença da poesia.

No caso de Joaquim Nabuco, quando da publicação de Pensées détachées et souvenirs, ele reconheceu:

Você nos dá juntos o homem público e o pensador. Esta obra, não feita agora mas agora publicada, vem mostrar que em meio dos graves trabalhos que o Estado lhe confiou não repudia as faculdades de artista que primeiro exerceu e tão brilhantemente lhe criaram a carreira literária. ${ }^{29}$

Artista chama Machado de Assis a Joaquim Nabuco; esse o ângulo de visada adotado para o exame da obra Pensées détachées et souvenirs. Apliquemse-lhe, pois, os critérios do crítico.

27. Cf. ASSIS. Obra completa em quatro volumes, v. IV, p. 118-119.

28. ASSIS. Obra completa em quatro volumes, v. III, p. 1197.

29. ASSIS. Obra completa em quatro volumes, v. III, p. 1342. 
Machado de Assis disse, dos pensamentos de Nabuco, que "valem e vivem pela observação exata ou nova, pela reflexão aguda ou profunda; não menos querem a originalidade, a simplicidade e a graça do dizer.", A "observação exata ou nova" vale aqui pela "inspiração", "o sentido íntimo" - que lhe cabe, na condição de crítico, identificar; o mesmo se pode afirmar da "reflexão aguda ou profunda". Nessa primeira metade da afirmativa, estamos perante a "alma" da poesia. Em seguida, "a originalidade, a simplicidade e a graça do dizer" equivalem aos aspectos técnicos, formais, dizem respeito ao "corpo" dado pelo escritor a suas idéias, seus pensamentos. A distinção era bem conhecida de Nabuco:

Não percebeis a diferença entre ideia e som, ou entre ideia e luz? A diferença entre o espiritualista e o materialista é que este último coloca a própria imaterialidade, ou o que mais lhe reveste a aparência, como seja a ideia, no domínio da matéria propriamente dita. Bem se o pode comparar a um fonógrafo, crente de que o pensamento, traduzido pelos sons do seu registo, está igualmente gravado no disco. (I: 182)

Ao pensamento, Machado de Assis atribui a palavra genérica de "substância" da obra, afirmando, ainda, que ela atrairá o leitor, pois "é aguda e muita vez profunda"; quanto à forma, diz que "é sempre bela", que há de atrair, por seus encantos, o leitor.

Avaliação praticamente idêntica foi feita por Émile Faguet, que leu o livro e escreveu sobre ele, sem conhecer o autor (pois julgava ser Joaquim Nabuco "évidemment un pseudonyme"), na revista Les Annales Politiques et Littéraires (Paris, 29 de setembro de 1907): "Nabuco excelle vraiment, quelquefois, comme vous avez dejà vu, à trouver une image neuve, forte et brillante pour exprimer une pensée que tout le monde peut avoir, mais que fort peu auraient avec un tour d'esprit aussi hereux:" - e cita em seguida um exemplo de seu agrado, no caso, aquele em que Nabuco afirma do século XIX que nele "o homem entrou de carruagem e saiu de automóvel." (III: 130 - adaptação nossa)

Opinião semelhante expressou Vicenso Morelli (Rastignac), que publicou crítica na Tribuna, de Roma, traduzida e publicada no Jornal do Comércio, do Rio de Janeiro, em 14 de janeiro de 1907: "Sabe [o autor dos Pensées] encontrar

30. ASsIS. Obra completa em quatro volumes, v. III, p. 1343. 
a forma mais correta e elegante para manter as melhores relações entre a razão e a fantasia, entre a matéria e o espírito, entre o sonho e a realidade." ${ }^{31}$

A matéria do livro inclui reflexões religiosas, filosóficas, morais, estéticas e políticas. Sua forma, segundo o crítico, deixa exposto o autor, "aberto às vistas por aquela forma lapidária que a memória retém melhor." O apelo à noção de "forma lapidária" aproxima Joaquim Nabuco da noção de verso, de aforisma, de dito tradicional, provérbio - "a maior unidade da linguagem cotidiana e, ao mesmo tempo, a menor espécie de composição poética." ${ }^{32}$ E o autor dos pensamentos não desconhecia essa região das reflexões; em muitos pontos coincidia a visão dele com a de seu crítico:

Em qualquer obra tereis que escolher entre a extensão e o acabamento, entre a profundidade e o brilho. (II: 97)

Sobressai mais o talento numa frase isolada de Schumann, por exemplo, ou num verso de Goethe, que numa longa peça dramática. Isso porque a inspiração não passa em geral de uma ideia, uma convicção, um estado d'alma. Somos nós que construímos em redor dela um imenso andaime, em geral pueril. (II: 154)

[...] O pensamento solto pode ser o registo de um relâmpago que vos atravessou o espírito, ou de um estado interior passageiro. É uma "moralidade" sem a respectiva fábula. É como se, em vez de atores para representar, o diretor de cena atirasse ao auditório, para ser meditada, a tese de que o autor cogitou tratar. Os pensamentos devem ser semeados, insinuados nas obras de imaginação, nunca desagregados nem descarnados. É verdade no entanto que o escritor só viverá pelos pensamentos que possam ser destacados de suas obras. (II: 174)

Não apenas a noção de "forma lapidária" é fundamental na poética de Machado de Assis: como observou Raimundo Magalhães Júnior, muitos dos temas de seus contos eram tomados a provérbios; muitas vezes, suas histórias

31. Artigo de Vicenso Morelli (Rastignac). In: ARANHA. Machado de Assis e Joaquim Nabuco: correspondência, p. 188.

32. "Le proverbe est ainsi la plus grande unité codée de la parole quotidienne, et em même temps la plus petite composition poétique." JAKOBSON. Étude du folklore, p. 73 
morais eram paráfrases de fábulas. ${ }^{33}$ No teatro de provérbios de Musset Machado de Assis aprendeu algo desse procedimento artístico; e também no seu teatro ele o empregou. O verso, ou, se se quiser, a concisão própria da poesia foi para ele a semente e o caminho da prosa. O mesmo se pode afirmar de muitos capítulos de seus romances. A isso, pode-se acrescentar, ainda, o gosto dele pelas máximas. Nabuco era um espelho em que se mirava o próprio Machado... ele, o mais acabado exemplo de um Esopo de casaca.

E aqui caberiam exemplos em que o pensamento alcança a densidade do poético, sem que necessariamente tenha sido posto numa imagem que lhe equivalha:

Guardai a dedicação depois de se ter apagado o amor, a veneração depois de ter perdido a fé, a gratidão depois de pagar a dívida, a generosidade depois de retirar a estima. (II: 9)

As renúncias cá na terra serão sempre proporcionadas à duração da vida que aspiramos: para viver nos filhos, muitos sacrifícios são necessários; para viver na posteridade, ainda maiores; para viver na eternidade, torna-se preciso o desprendimento total. (II: 15)

Em passagens tais, pode-se pressentir outro grande livro de "pensamentos", "anotações", "poesia em prosa" - a obra Cadernos de João, de Aníbal Machado. É difícil, depois de ler os Pensamentos soltos de Nabuco, não ficarmos convencidos de que ele foi fonte e inspiração para o autor de João Ternura. Examinemos, por justaposição, apenas uma passagem em que Aníbal Machado parece ter "aperfeiçoado" Nabuco:

Consideremo-nos todos gotas d'água no oceano humano; os gênios são suas fosforescências. O eu, o sentimento pessoal, é que induz cada gota a se julgar um oceano, destruindo em todos nós o verdadeiro senso da proporção entre o indivíduo e a massa. (III: 206)

Ninguém precisa sair de si para participar do ilimitado. Cada qual está perto do longe e contém o Todo, como a gota de água é mar dentro do mar. $^{34}$

33. Cf. MAgAlhães JÚNIOR. Vida e obra de Machado de Assis, v. I, p. 233.

34. MACHADO. Cadernos de João, p. 48. 
Grande benefício trazem os livros, uns aos outros. No fragmento dos Cardernos de João, caminha o pensamento do particular ao ilimitado - há como que uma visão zen budista das relações do "eu" com o mundo; no dos Pensées détachées, vai o pensamento da imensidão à singularidade dos indivíduos - há como que uma moralidade acerca do egocentrismo.

Afirma Machado de Assis, em sua crítica ao livro de Nabuco, que sente "a beleza e a verdade particular" desses pensamentos soltos - apresentandose aí, explícita, a condição de toda arte, a "perfeição", vale dizer, o ajuste, a "harmonia" entre a "substância" e a "forma".

É curioso que Machado de Assis, para falar dos pensamentos ao autor deles, que os expressou em francês, os tenha posto em português - num texto que traz as marcas formais de uma carta; ele, Machado, que nunca se inibiu de incluir citações em línguas estrangeiras nos seus textos os mais comuns, publicados em jornais destinados ao grande e heterogêneo público; ele mesmo, que terminou um dia uma de suas crônicas, falando do gosto daquela época pelas óperas, com estas palavras: "É a nossa única paixão, - a maior, pelo menos. Tout finit par des chansons, em França. No Brasil, tout finit par des opéras, et même um peu par des operettes... Tiens! j’ai oublié ma langue. ${ }^{35}$ Pois ele mesmo pôs em português, para Joaquim Nabuco, os pensamentos que Joaquim Nabuco escrevera em francês. Tudo isso, e a aplicação do "pequeno código de crítica" de que dispunha, e mais o esforço analítico de trazer alguns exemplos, para demonstrar o que afirmava, e, ainda, o destinatário implícito nessa atitude - o leitor que não conhece o livro (e talvez não o francês) -, tudo isso ultrapassa a perspectiva de ser o autor dos escritos seu único destinatário, tudo isso confere a essa carta a estrutura de peça de crítica literária. Mário de Alencar teve razão, ao selecioná-la para o volume de crítica machadiana que organizou.

No prefácio ao livro, Nabuco, com a mesma arte com que compôs todo o livro, define assim a sua matéria:

Os reflexos do ideal assemelham-se às pequeninas espécies que a noite gera em silêncio na sua escuridão. Para poder fixar-lhes os contornos vivos seria mister discerni-los na penumbra, onde surgem para logo morrerem. Vestem os mesmos tons que elas, - tintas grisalhas do anoitecer, quando muito o burel amarelado do crepúsculo. Só em espíritos muito

35. ASSIS. Obra completa em quatro volumes, v. IV, p. 894. 
altos, muito puros, passam às vezes algumas que tenham asas de ouro. Tais imagens só podem ser manejadas à sombra mesma da meditação em que nasceram. Não é, pois, sem receio que me atrevo a expor à luz do dia algumas dessas impressões que escapam sempre e se destroem ao pensamento como falenas à luz. ${ }^{36}$

É disso que trata o livro: "impressões" fugidias, "imagens" fugazes e delicadas, "reflexos do ideal", comparáveis "às pequeninas espécies que noite gera em silêncio na sua escuridão." Muitas são esbatidas, vestem-se das "tintas grisalhas do anoitecer" - podem ser pouco claras; algumas "têm asas de ouro" brilham, movem-se no território da poesia, atendendo à observação de Machado de Assis -"Todos gostarão dessa forma de dizer, que para alguns será apenas poética..." Desses pensamentos, uns pouco claros, outros luminosos, afirmou Émile Faguet: "Il y en a, de ces pensées, qui ne sont pas faciles à comprendre; il y en a, ce me semble, qui ne valent guère la peine d'être comprises; il y en a de neuves et de curieuses que vous aurez plaisir à méditer., ${ }^{37}$

O próprio Joaquim Nabuco, talvez prevendo observações como as de Faguet, ou reconhecendo-as como inevitáveis, anotou:

Assim alguma vez me acontece escrever uma frase sob uma impressão qualquer; apagada a impressão, fica a frase, mas já não tem vida, não significa nada. Escrevi por exemplo: "Sem reservar o quinhão de Deus, não é possível gozar de nada." Hoje encontro nesta frase muitos sentidos, porém, daquilo que senti e me urgiu exprimir ao tomar esta nota fugitiva, nada ficou, de nada me lembro. Ficou a frase, com seu sentido claro, geral e vago, destituída do pensamento que já encerrou. A alegria interior que ela teve missão de perpetuar para mim evaporou-se. (II: 50)

E mais apropriadamente ainda:

Depois de escrever uma página com a convicção de ter posto nela toda a vossa alma, admira-vos ver que outros a lêem sem emoção. O primeiro motivo é que não conseguistes fundir vossa alma nessa página, e assim

36. NABUCO. Pensamentos soltos, "Prefácio", página não numerada.

37. FAguet. Pensées détachées, de Joaquim Nabuco. In: ARANHA. Machado de Assis \& Joaquim Nabuco: correspondência, p. 182. 
não demorará o momento em que nem vós mesmos, que a escrevestes, podereis discernir, à leitura, vossa inspiração. O segundo motivo é a falta de coincidência entre o vosso estado de espírito, no momento de escrever, e o de quem vos lê. O leitor teria que receber da leitura o mesmo choque que vos causou a inspiração. É coisa impossível; em vós houve transbordamento; foi o excesso que despejastes na página; o leitor recebeu, ao invés da torrente, as sobras. Há ideias que podem ser reduzidas a fórmulas; são as que se tornam em conhecimentos humanos, em resultados. E há ideias intransmissíveis; são estados de alma. Ninguém jamais apreendeu o estado de alma de outra pessoa. (II: 186)

Nesse fragmento (II: 186), de aguda observação sobre as relações da subjetividade consigo mesma e com as outras, há algo que circula na região das reflexões de um Fernando Pessoa, por exemplo. E não é só aí; veja-se mais isto: "A comoção que produz em nós o pensamento de outrem já é um pensamento nosso, e portanto varia de indivíduo a indivíduo, como as cópias de quadros célebres." (II: 185)

Nabuco bem reconhecia a natureza da matéria a ser aprisionada na forma escrita, pois anotou aqui e ali, trechos do que poderíamos chamar de uma poética:

A eletricidade mental é o que mais dificilmente conseguireis transmitir à página que escreverdes; a frase pode registar a ideia que vos acudiu sem nada comunicar da emoção que ressentistes, e, se não fixardes essa emoção, a idéia parecerá aos outros fria e sem valor. (II: 60)

[...] Não há verdadeira poesia que não venha do fundo comum, indiviso, da humanidade. (II: 85)

A impressão, transformada em ideia, perde logo metade de sua força. Quando a admiração permite pensar em outra coisa já não está intacta. Logo que o objeto do nosso enlevo desperta um conjunto de ideias associadas, diminui proporcionalmente nosso entusiasmo. Este parece sofrer uma remoção; perde do seu calor com essa irradiação larga e essas vibrações rápidas. A impressão, quando profunda, não se aparta do próprio objeto, não lhe compara nada, absorve tudo nele. (III: 41)

A natureza do trabalho de arte, portanto, não lhe é estranha: ele a conhece como poucos - como artista que executa, e como crítico, que anda de par com o artista. Quando a executa, dificilmente poderia alguém fazer melhor do que ele, 
como neste fragmento que é um todo, em que Machado de Assis, num dos pontos altos de sua avaliação, viu "uma imagem de contrastes e imperfeições relativas":

A borboleta nos acha pesados, o pavão mal vestidos, o rouxinol roucos, a águia rastejantes. (III: 78)

Ou neste outro, em que o fundo moral se transfigura em imagem:

Houvesse uma agência para troca das felicidades que todos nós invejamos uns aos outros, e cada um iria trocar a sua. (III: 107)

Dessa imagem Machado de Assis nos deu uma tradução melhor do que a de Carolina Nabuco, pela economia, pela justiça que faz à expressão do pensamento pelo autor traduzido, pelo distanciamento que guarda por não introduzir na ideia a primeira pessoa gramatical:

Se houvesse um escritório de permuta para as felicidades que uns invejam aos outros, todos iriam lá trocar a sua.

E Nabuco:

S'il y avait un bureau d'échanges pour les bonheurs que l'on envie à autrui, tout le monde y irait échanger le sien. ${ }^{38}$

Apenas a economia do "Se" hipotético inicial da tradução de Carolina Nabuco poderia ser uma boa sugestão à pena de Machado. É possível que a intenção secreta de Machado fosse revelar a Nabuco que seus "pensées" não só cabiam nela, mas fariam bem à língua portuguesa.

Ainda no território das figurações, não escapou à imaginária do escritor, para representação de um dos detalhes sua filosofia moral, o pensamento matemático:

A família é um triângulo cuja hipotenusa é a criança. O quadrado construído sobre a hipotenusa é igual à soma dos quadrados construídos sobre os dois outros lados. (I: 252)

38. NABUCO. Pensées détachées et souvenirs, livre III, pensée 107 (na edição francesa: CVII). 
Em todos esses exemplos - e muitos outros poderiam ser trazidos do livro - a "forma lapidária" é perfeita. Não escaparam a Machado de Assis a condição rara e a disciplina necessárias a este gênero de criação: "As faculdades que exige são especiais e raras; e é mais difícil vingar nela que em composição narrativa e seguida."

Mais uma observação de Machado, sobre um dos pensamentos do primeiro livro (I: 129):

Sabe-se o que era a vida dos anacoretas, mas dizer como V., que "eles só conheceram dois estados, o de oração e o de sono, e provavelmente ainda dormindo estavam rezando", é pôr nesta última frase a intensidade e a continuidade do motivo espiritual do recolhimento, e dar do anacoreta imagem mais viva que todo um capítulo.

Elogio justíssimo, merecedor, ele também, de todos os elogios porque dizer isso assim é revelar ao leitor a máquina do poema; é, sobre ter bom gosto, emprestar esse gosto a toda a gente, para nos valermos das palavras do próprio Nabuco (III: 197).

E há mais, muito mais, no livro - e lembremo-nos de que o interesse aqui é somente a literatura; há crítica, há teoria da poesia, há autocrítica. Senão, vejamos, em primeiro lugar a teoria:

Em geral essa gente delicada e exigente [os poetas] tem unicamente o talento que deriva do seu método de trabalho... Na caça à rima, topam com efeitos e combinações inesperadas; cavando as palavras, descobrem, por vezes, um veiozinho de ouro... Chegam pela palavra ao pensamento, não pelo pensamento à palavra, como todo verdadeiro criador. (II: 147)

A faculdade poética é, em última análise, a imaginação desacorrentada. O verdadeiro poeta é o homem que se sente rei de seu pensamento como a águia, dos ares, e é servido por suas ideias numa esfera onde nada o pode atingir. No poeta, há algo do criminoso imaginário, do pecador que se absolve a si mesmo, do espírito que quebra as convenções sociais para criar sua própria lei irresponsável. A verdade sobre a poesia nunca se afastará de concepção antiga que a tinha por uma das formas de delírio. (III: 149) 
Ora, um poeta não pode ser um fonógrafo: ele há de pôr o pensamento na forma necessária - única forma que atende à necessidade da expressão. E como a faculdade teórica anda casada com a da crítica, uma passagem de autocrítica:

Personagem que Deus não cuidou de convocar quando criou o mundo, o crítico faz questão de estabelecer uma hierarquia nas obras da criação e nas obras do espírito humano. Assim geram-se inveja e desprezo, e o desânimo dos maiores, ante injustiças; assim ficam eles à mercê de seus inferiores, os estéreis. A única estética sadia é a que não cogita de medir impressões produzidas por tipos diferentes, a que coloca no mesmo plano todos os grandes esforços intelectuais da humanidade, fundindoos no gênio humano, como as cores de fundam na luz sem sobressair nenhuma. (III: 141)

Quanto às outras facetas do livro, a filosófica, a religiosa, a moral, a política - esferas, muitas vezes, do pensamento puro -, soube o autor muito bem defender sua pertença ao campo da literatura, como fez nesta passagem:

Ao lado da literatura mestra do nosso tempo, que foi, é mister confessar, para a raça latina, a literatura do adultério, existe felizmente o trabalho dos pensadores e dos pesquisadores, que tantas ideias novas semearam, uns, e tantas coisas esquecidas restauraram, outros.

Mas os homens de letras arrogam-se o direito de colocar todos estes fora da literatura. (II: 92)

Crítico e criticado tinham afinidade profunda, embora Machado de Assis tenha dito, na mesma carta que é um dos objetos deste artigo: "Se alguma vez discordo do que leio, sempre agradeço a maneira por que acho expresso o desacordo." Veja-se este "pensamento":

Love bridges everything, "o amor serve de ponte entre todas as condições sociais". É ponte com efeito, que liga raças, línguas, fortunas e naturezas, mas é ponte levadiça. (II: 205$)^{39}$

39. Nesse fragmento, na edição dos Pensamentos soltos (1937), está "Loves". 
Não parece isso uma das tiradas do autor das Memórias póstumas de Brás Cubas? É de crer-se que o amigo diplomata era mais que amigo: deve ter sido irmão mais moço, como Carlos Magalhães de Azeredo e Mário de Alencar foram os filhos que teve, sem ter sido o responsável pela transmissão a eles do legado de nossa miséria.

No centenário do reconhecimento de Machado de Assis como crítico literário.

\section{Joaquim Nabuco as an artist}

Abstract: This article analyses Joaquim Nabucos work written in French, Pensées détachées et souvenirs, as a piece of art. Joaquim Nabuco didn't considered himself an artist. In spite of this, Machado de Assis, a great writer and a great critic of that time, in a letter which is a piece of literary criticism, considered him an "artist". The letter was addressed to the Pensées détachées et souvenirs' author. Keywords: Brazilian Literature, Joaquim Nabuco, Machado de Assis

$$
\text { Referências }
$$

ALENCAR, Mário de. Crítica por Machado de Assis (Coleção feita por Mário de Alencar). Rio de Janeiro: Garnier, [1910].

ARANHA, Graça. (Org.). Introdução. In: Machado de Assis e Joaquim Nabuco: correspondência. 3. ed. Rio de Janeiro: Academia Brasileira de Letras/Topbooks, 2003. p. $19-86$.

ARANHA, Graça. (Org.). Machado de Assis e Joaquim Nabuco: correspondência. 3. ed. Rio de Janeiro: Academia Brasileira de Letras/Topbooks, 2003.

MORELLI, Vicenso. Rastignac. In: ARANHA, Graça. (Org.). Machado de Assis e Joaquim Nabuco: correspondência. 3. ed. Rio de Janeiro: Academia Brasileira de Letras/Topbooks, 2003. p. 187-191.

ASSIS, Machado de. Crônicas (1864-1867). Rio de Janeiro: Livro do Mês, 1962.

ASSIS, Machado de. A semana (1892-1900). Rio de Janeiro: Livro do Mês, 1962. 3 v. ASSIS, Machado de. Obra completa. Rio de Janeiro: Nova Aguilar, 1994. 3 v.

ASSIS, Machado de. O ideal do crítico. In: Obra completa em quatro volumes. Rio de Janeiro, Nova Aguilar, 2008. v. III, p. 1101-1104.

ATAíDE, Tristão de. Machado de Assis, o crítico. In: ASSIS, Machado de. Obra completa, v. III, p. 779-783. 
CANDIDO, Antonio. Nota inicial. In: COUTINHO, Eduardo F.; OLIVEIRA, Teresa Cristina Meireles de. Empréstimo de ouro: carta de Machado de Assis a Mário de Alencar. Rio de Janeiro: Ouro sobre Azul, 2009. p. 11.

CARVALHO, José Murilo de. As duas repúblicas. In: ARANHA, Graça. (Org.). Machado de Assis e Joaquim Nabuco: correspondência. 3. ed. Rio de Janeiro: Academia Brasileira de Letras/Topbooks, 2003. p. 9-18.

FAGUET, Émile. Pensées détachées, de Joaquim Nabuco. In: ARANHA, Graça. (Org.). Machado de Assis e Joaquim Nabuco: correspondência. 3. ed. Rio de Janeiro: Academia Brasileira de Letras/Topbooks, 2003. p. 181-186.

HOLANDA, Sérgio Buarque de. (Dir.). História geral da civilização brasileira: II - O Brasil monárquico - do império à república. São Paulo: Difusão Europeia do Livro, 1972.

HOUAISS, Antônio et al. Introdução crítico-filológica. In: ASSIS, Machado de. Poesias completas: Crisálidas, Falenas, Americanas, Ocidentais. Texto estabelecido pela Comissão Machado de Assis. Rio de Janeiro: Civilização Brasileira, 1976. p. 31-119.

JAKOBSON, Roman. Étude du folklore. In: Une vie dans le langage. Paris: Les Éditions de Minuit, 1984. p. 73-97.

LESSING, G. Ephrain. Laocoonte. Madrid: Nacional, 1977.

MACHADO, Aníbal. Cadernos de João. Rio de Janeiro: Nova Fronteira, 2002.

MAGALHÃES JÚNIOR, Raimundo. Vida e obra de Machado de Assis. Rio de Janeiro: Civilização Brasileira, 1981. $4 \mathrm{v}$

NABUCO, Joaquim. Pensamentos soltos. Traduzidos do francês por Carolina Nabuco. São Paulo: Nacional, 1937.

NABUCO, Joaquim. Pensées détachées et souvenirs. Paris: Hachette, 1906.

NOVO dicionário de história do Brasil. 2. ed. São Paulo: Melhoramentos, 1971.

SKIDMORE, Thomas E. Uma história do Brasil. 2. ed. São Paulo: Paz e Terra, 1998. 